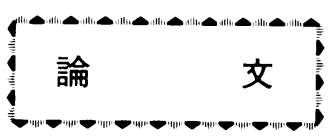

\title{
耐熱プラスチックフィルムを応用した ダイクロイックミラーの開発
}

\author{
正会員 丸山 辰 雄* 战会員 佐藤 光治*
}

\section{Development of dichroic reflector based on plastic films Tatuo Maruyama (Member), Koji Sato (Member)}

(Lamp \& Lighting Laboratory, Toshiba Lighting \& Techonlogy Corporation)

\begin{abstract}
This paper describes the development of new dichroic reflector using the substrate of plastic film. The conventional substrate of dichroic reflectors for spot-lights is made of glass or aluminum, and recently the plastic substrate by injection molding is available.

So, at first, concerning characteristic as to reflector, three kinds of substrate, glass, aluminum, and plastic are compared with. As the result of comparison, we consider plastic films are applied to substrates of dichroic reflector. Examining heat resistance, stability, and optical characteristics of new dichroic reflectors using plastic films, sufficient results for reflector of spot-light are obtained. Especially, deposited protective coating on reflecting surface, higher stability is obtained. So, the spot-light using asymmetric reflector made of plastic film with $12 \mathrm{~V} 50 \mathrm{~W}$ halogen-lamp has been developed.
\end{abstract}

\section{1.はじめに}

比較的高照度を与える照明器具の反射鏡として，放射による被 照射物の熱的損傷を減少させるため，光学多原膜の干涉作用在心 用した赤外放射を透過または吸收し可視放射を文射するダイク口 イックミラー（以下DMと䛉寺）が朋いられている。近行では八 ロゲン電球の普及に上も交って, 后舖の重点照明（スポットライ 卜）などの店内照明器具にも数多く使用されるようになってき た。この重点照明に用いられることにより，DMは，いままでの 熱的損傷を減少させるといら機能だけでなく，その特徵を十分に 発捕して新しい照明演将・器具デザインを飤り出すとと老叮能见 している.

照明演出上では，“明るさ”“暗さ”だけでなく，被照射物の “色”在制御し，被照射物をより強調するDM付き電球 ${ }^{1) 2}$ や反射 鏡引が開発された。また，器具デザイントではDM目身を泪接見 えるようにし，反射鏡孛透過した光を外钼デザインとして積極的 に取り人れたスケルトンタイプのスポットライトも開発された。

・方，DMの基板となる材料面では，ガラス，アルミニッム， プラスチックが知られている。占くからDMの基板にはガラス が讲いられ，規在においても耐熟性，表面処理が良好であること からもっとも多く採朋されている。1989年には，よりDMの用

\footnotetext{
*東芝ライテックス制式会补研究折

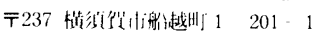

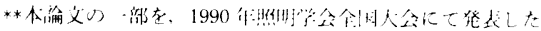

途や使用場所を拡大できるよら，ガラス基板の破損時の娔険性を 解消し，かつ大型化しても軽量で経済性のよい反射鏡としてアル ミニウム基板を用いた DM が開発されている 法，プラスチック射出成形による文射鏡がデザイン性のあるスポ ットライトに羘いられている゙．

筆者は，DM在朋いた照明器具の外観デザイン，照射パターン 在さらに多様化するため, 形状の间度が槀く多品種少荲生産に

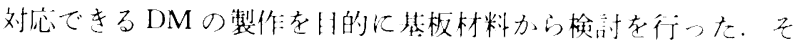
の結果，反射鏡形状に成形したプラスチックフィルム表面に真空 蒸着にて光学薄膜をコーティングL DM在製作し，央用㞴能な 性能在得ると其に，プラスチックフィルム基板 DMの特徽を生 かした舆明湂!孝開発したので報告する。

表 1 現在使用されているダイクロイックミラーの比較

\begin{tabular}{c|c|c|c}
\hline & ガラス & 金 属 & プラスチック(現行) \\
\hline 代表的材料 & ホウケイ酸ガラス & アルミニウム & ポリエーテルイミト \\
\hline 成形法 & プレス & スピニング & 射出成形 \\
\hline 上限連続使用温度 & $250^{\circ} \mathrm{C}$ 以上 & 約 $250^{\circ} \mathrm{C}$ & 約 $160^{\circ} \mathrm{C}$ \\
\hline 許容最大寸法 & $\phi 250$ & $\phi 500$ & $\phi 200$ \\
\hline 基板肉厚 $* 11$ & $3 \sim 5 \mathrm{~mm}$ & $0.8 \sim 1.2 \mathrm{~mm}$ & $2 \sim 3 \mathrm{~mm}$ \\
\hline 重量 $\left.{ }^{\circ} 1\right)$ & $260 \mathrm{~g}$ & $100 \mathrm{~g}$ & $120 \mathrm{~g}$ \\
\hline 形状の自由度 & 良好 & 回転体に限る & 優秀 \\
\hline
\end{tabular}

*1) 開口径 $\phi 150 \mathrm{~mm}$ ，深さ $50 \mathrm{~mm}$ 程度の反射鏡の場合 


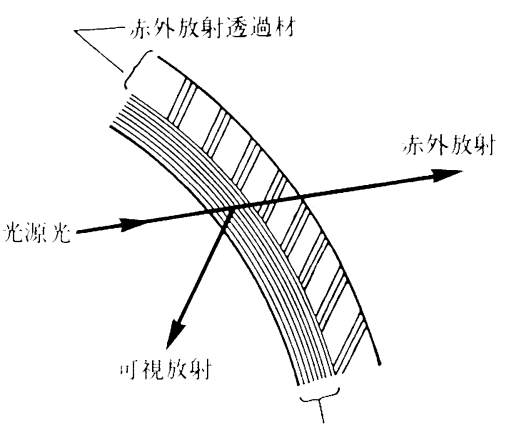

叮视放射父射・赤外放射透過屏

a)ガラス・フラスチック基极の埸令

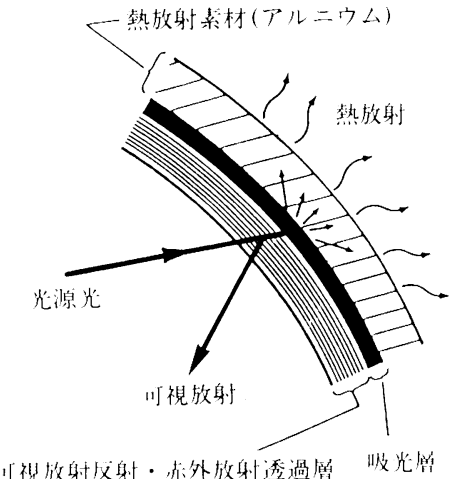

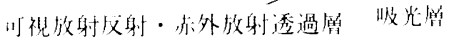

b) アルミ二ウん基板均埸公

図 1 坮行多イクロイックミラーの模成

\section{2. ダイクロイックミラー (DM) の現状}

表 1 に，現在使朋されている DMの比較在示寸。表 1 亿小し た 3 種類（ガラス，金属，ブラスチック）のDMは基板材料々 基板の成形今法の难で異去のており，そのために耐熱性，重㫣，

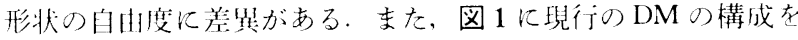

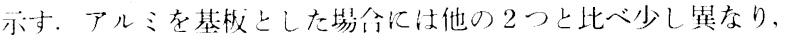

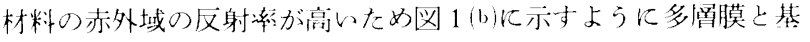
板表面の中䦌飞吸光圆が設けられている。

耐熱性法材料自身に依存寸る利熱温度上高温使用に上万多層膜 の耐久性に関係するが，どちらに执いてもがラス基板が最も優れ ている、しかし、アルミ基板もこれに集ずるものであり、今後の 開発によりさらに耐熱性:向上:寸るものと思われる，文射鏡の最 大許谷小法は表面処理：程に活济依存寸るが，ガラス基板につい ては反射鏡の大型化比々もなら重量増大と衣面处理装置への基板 取付うj法の制約から，成形できる小法に限界がある。射出成形を 用いたプラスチック成形品については大型用の成形機が必要であ るとと，金型投资が增人することから，央用上寸法が制限され る. 耐熱性及び詐谷寸法の観点からはガラスかアルミを用いるこ とが有効であると音える。

しかしながら本献の開発の狙いは，ガラス基板上|间等美外钼デ ザイン州:を持たせながら，さらに形状の白目度を向、させ，椂々
な器具デザインや配光が得られるDM を製作することである。 ガラス基板の壦合は，此較的いろいろな形状が叮能ではあるが成 形用金型が高怵であり，現在のところ必ずしも形状の自佣度在向 上させる上で適した基板と沬いいがたい。アルミ基板の塕分はス ピニング成形を用いれば比較的父体に基板を製作できるが，形状 が回転体に限られ，さらにアルミ基板で沽材料の透光性を生かし た器具デザインができないまた，射出成形によるプラスチック 基板の最大の難点は成形品の肉惊が 2 - 3 mm 必要であるため, 材料費が増大寸るととと，熱容量が増し高温化比刘心できないこ とである。

そこで、プラスチック基板の肉卧をできるだけ薄くすることが できれば，材料費を低減させるとともに，熱容量をトげることが でき，射怙成形によるプラスチック基板に比べ基板温度の低温化 が期待できる、基板薄肉化のためにプラスチックフィルムをDM

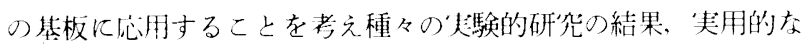
父射鏡の開発を行った。

\section{3.フィルム基板を用いた DM の開発}

\section{1 開発目標}

上述したよ5に，プラスチックフィルム基板を用いたDMの 開発上しては样々な形状を容易汇製作できるようにすることが最 大の月標であるが，現行の射出成形によるプラスチック基板の从

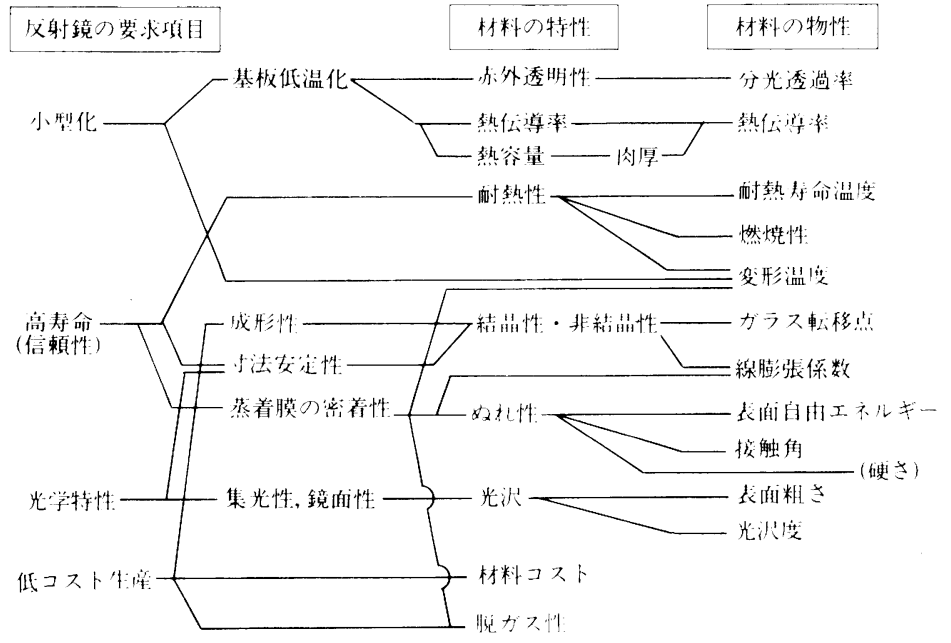

表 2 ブラスチックフィルムの此較项| 
点である耐熱性:の收良为含め以トのような開発目標を定めた。

(1) 成射鏡形状を様々な形状に作製できるようにする。

角型や㮠四型圭よ゙の叮転体形状以外の实現

(2) プラスチックの材料費をフィルムを用いるととで低減し，

より耐熱温度の高いブラスチック材料の利用を叮能とする。

$200 \mathrm{C}$ 前後の耐熱性: と耐久性:

(3)比重の小さんプラスチック材料の特長を生かした超軽量な 反射鏡を実現する。

\section{2 プラスチックフィルムの選択}

表 2 にプラスチックフィルムを選扰する上での調査比較項目を 示す。このらち特飞重要交項日は, 耐熱性, 赤外透明性: 表面光 沢度である。

耐熱性，赤外透明性は，よりDMを光源に近づけて使用する ことを可能とするものであり，特に赤外透明性が高いほど光源か らの赤外放射の自己吸収による DM 基板の温度上昇老防ぐこと ができる、この観点からもフィルムを採用することは, 熱容量を 小さくするととだけでなく郝透明性を向上させるととにつなが る. をた，高的表面光沢度は正反射率を高め集光性の良的射鏡 を可能上する．フィルム材の供給時に光沢度が小さければ最終的 に反射鏡としての鏡面性が期待できない，これらを満足するプラ

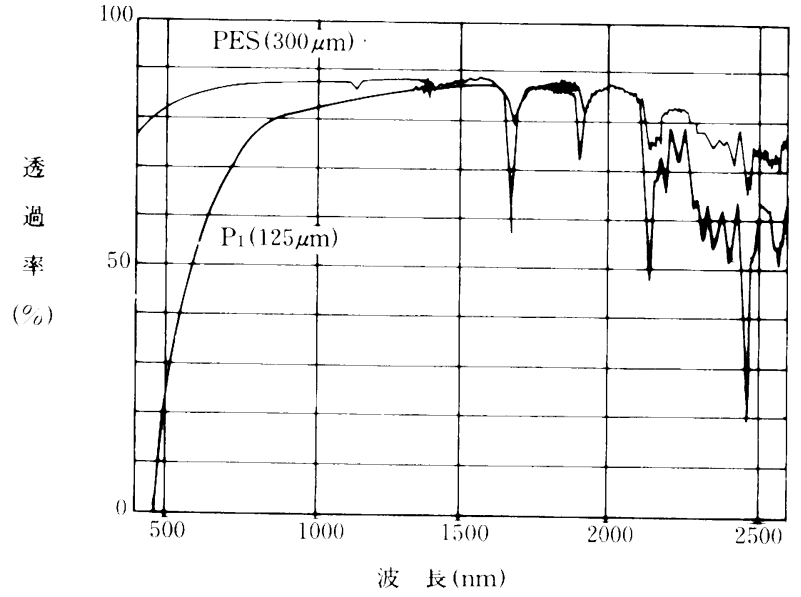

図 2 PES, PI の分光透過棌

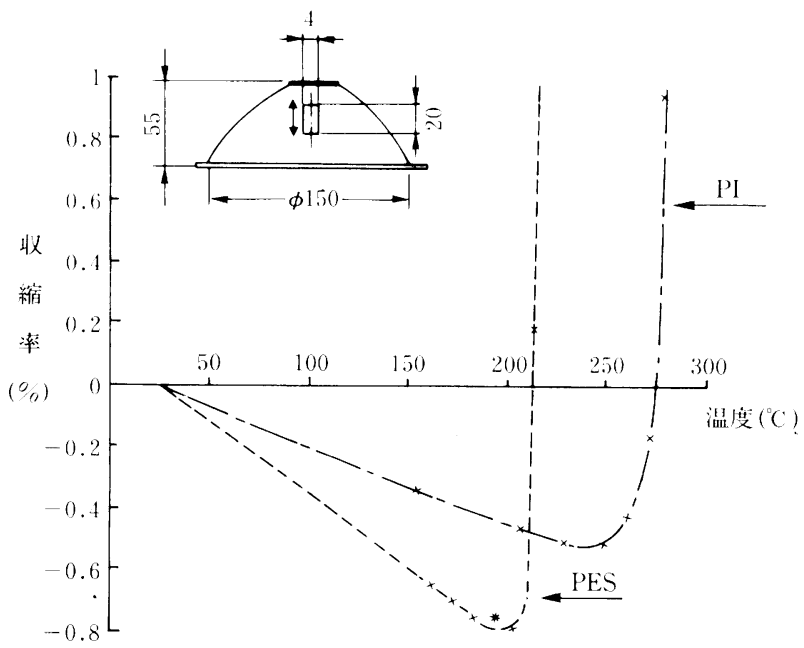

図 3 TMA に上る收樎性の試験結果
スチックフィルムとして, ポリエーテルサルフォン (以下, PES と記す)，ポリイミド（以下，PI と記す）を選执した。

PES及びPIフィルムは, 何種類かの厚さのものが供給されて いるが，合同は，できるだけDM 基板の岡性を高めるため，供 絵されることができる最大の児さである, 早さ $300 \mu \mathrm{m} の$ PES ᄀ イルムと児さ $125 \mu \mathrm{m}$ の PIフィルムを選定した。图 2 にそれぞ れのフィルムの分光透過率走寸. PES, PI と女赤外域の約 $2000 \mathrm{~nm}$ まで $85 \%$ の透過摔老持つ。さらに, PES 汀視域の透 明性も高くガラス基板に類似した装飾性も期待できる。

表面光沢性については, 成形前後の状態を 3.3 .3 で述べる.

\section{3 プラスチックフィルム基板製 DM の性能}

プラスチック基板製 DMの基本特性を確認するために，厚さ $300 \mu \mathrm{m}$ の PES フィルムと厚さ $125 \mu \mathrm{m}$ のPIフィルムを開い徍 $150 \mathrm{~mm}$ の回転放物面形状に成形した. 成形した基板の重量は,

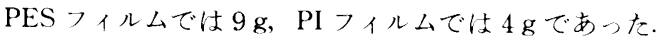

基板にプラスチックフィルムを用いたDMの性能として，こ こでは, 高温時の寸法安定性, コーティングした光学薄膜の信頼 性（㴽着性），反射面の鏡面性の 3 点について報留する。

\subsection{1 熱的寸法安定性}

成形品の高温時の寸法安定性を TMA (Thermal Mechanical Analysis）にて測定した. 測定に用いた成形品の形状は, 開口径 $\phi 150 \mathrm{~mm}$, 深さ $60 \mathrm{~mm}$ の回転放物面で, 絞り比（深さ/開口 径） 0.4 である. 舷り方向に $20 \mathrm{~mm}$, 幅 $4 \mathrm{~mm}$ K成形品の中央部 を切断しサンプルとした. PES及びPIフィルムのサンプルを昇 温係数 $5{ }^{\circ} \mathrm{C} / 1$ 分で温度上昇させ, 室温時の形状に対しての収縮 率変化を測定した. 結果を図 3 亿示す. 成形による内部灾力のた め, PES フィルムの場合は $200^{\circ} \mathrm{C}$, PI フィルムの場合は $250{ }^{\circ} \mathrm{C}$ を境に急激な収縮を示し，形状化大をな変化をもたらす，これら の結果はフィルム材料のガラ、転移点温度と類似し，ガラ又転移 点が寸法安定性老決める代表的な值であるととがわかる.

また, 同様の成形品を 3 時間オーブン中に高温で放置し, その 深さ方向の寸法変化を調べた. 初期深さ寸法に対して, 加熱処理 後の深さ寸法の変化率を寸法保持率として表 3 亿小寸. TMA の 試験絬果を反映し, PESフィルム成形品は $180^{\circ} \mathrm{C}$, PI フィルム は $240{ }^{\circ} \mathrm{C}$ をで法保持率は $100 \%$ であった。

ここで確認した収縮率変化と寸法保持率は, 反射鏡の最大使用 温度に関係するだけでなく，光学薄膜をコーティングするトでも 重要な要因と卒る。

\subsection{2 光学多層膜の信頼性 (密着性)}

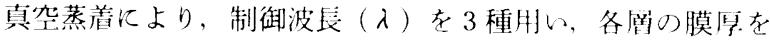

表 3 オーブン加熱による収維性の試験結果 (高温下 3 時間後の寸法保持率)

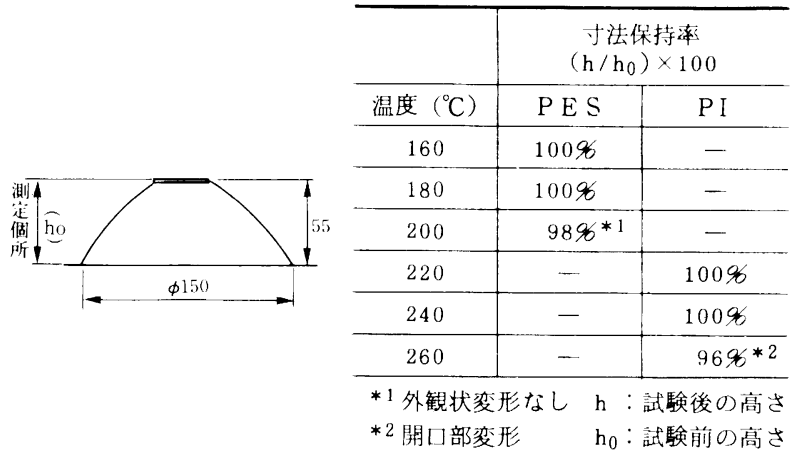


表 4 プラスチックフィルム基板 DM の信頼性試験

\begin{tabular}{|c|c|c|c|}
\hline 試験項目 & 内 & 結 果 & 参考規格 \\
\hline 付着力試験 & 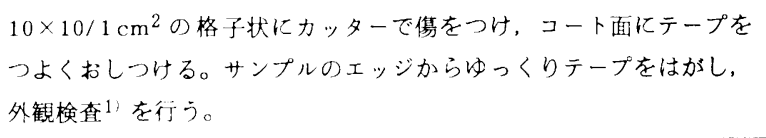 & 異常なし & MIL-M-13508C \\
\hline 温度試験 & $\begin{array}{l}\text { 高温中に } 100 \text { 時間放置し，その後付着力試験を実施する。(PES } 180 \\
\left.{ }^{\circ} \mathrm{C}, \mathrm{P} 1240{ }^{\circ} \mathrm{C}\right)\end{array}$ & 異常なし & \\
\hline ヒートショック試験 & $\begin{array}{l}\text { ヒートショックに適合する装置（急激な温度変化が可能なもの）にて } \\
\text { - } 20{ }^{\circ} \mathrm{C} 30 \text { 分, } 180{ }^{\circ} \mathrm{C}(\mathrm{PES}), 240^{\circ} \mathrm{C} \text { (P I ) } 30 \text { 尔を } 300 \text { サイクル } \\
\text { 実施する。 }\end{array}$ & 異常なし & \\
\hline 温湿度試騃 & $\begin{array}{l}95 \% \text { 以上の相対湿度で温度 } 40^{\circ} \mathrm{C} \text { に保たれた試験槽にサンプルを } 300 \\
\text { 時間放置し，その後付着力試験を実施する。 }\end{array}$ & 異常なし & $\begin{array}{l}\text { MIL-M-13508 C } \\
\text { MIL-C- } 675 \mathrm{~A}\end{array}$ \\
\hline 曲げ試験 & 曲げ半径 $1 \mathrm{~cm}$ にて外曲げ，内曲げを行い外観検査を行う。 & 異常なし & \\
\hline 溶解性試験 & $\begin{array}{l}45 \mathrm{~g} / 1 \ell の \text { 食塩水に室温にて } 24 \text { 時間浸し，その後柔らかい布で食塩水 } \\
\text { を拭き取り付着力試験及び外観検査を行う。 }\end{array}$ & 異常なし & MIL-C-675 A \\
\hline
\end{tabular}

1) 外観検查：目視できるクラックや白獨などの表面の異常がないかを確認する。

$\lambda / 4$ とした合計 23 層の光学多層膜を成形品表面にコーティング した．使用したコーティング材は二酸化チタン $\left(\mathrm{TiO}_{2}\right)$ 上 : 酸化 ケイ素 $\left(\mathrm{SiO}_{2}\right)$ である。また，一般に低温での蒸着は，膜が緻密 化されず密着力が低下し，水分の脱吸着の影響が大きくなるの で6)，ここでは成形品が蒸着時に基板変形を伴わない程度にでき るだけ基板加熱を実施した。図 4 亿製作したPES 基板 DMの分 光义射摔孝示吉。

光学多層膜の信頼性として，特に膜上基板の密着性の観点から 評価を行のた。表 4 亿は, 前章と同様のPES フィルム成形品及 びPIフィルム成形品に多曾コーティングし, 約 $5 \mathrm{~cm} に$ 切断し たサンプルの信頼性:試験結果を示す。信頼性試験として米国 MIL 規格が比較的短期間で評晌できる試験評価方法であり一般 によく用いられるが，照明月判 DM は光源点灯時，高温状態とな り室温との温度善が大きい噮境で使用されるととを考慮し，MIL 規格を参考とした試験の他に試験項月をさらに追加した．PES， PI フィルムの DM は共にいずれの試験項日に対しても異常は認 められなかった。 てれらの試験結果により，フィルム基板 DM 沬照明用反射鏡として十分交信頼性があるものと判断される。

一般に，プラスチック基板はガラスや金属基板に比べて耐熱温 度が低い。今回, 開発したDMもより高出力の光源と組み合わ せた場合，特にPESフィルムについては信頼性を高めることが 望をしい

そこで，より高出力の光源と組み合わされた場合の信頼性を向 トさせるお法としてプライマーコートかトップコートを施すこと が考えられるため, 光学多層膜が蒸着された PESフィルム基板 $\mathrm{DM}$ Kゾルゲル法により厚さ $1.2 \mu \mathrm{m}$ の $\mathrm{SiO}_{2}$ のトップコートを施 し, 約 $5 \mathrm{~cm}$ 角に比断したサンプルを準備し上述のサンプルに追 加した。陚験詊価ち法としては, $500 \mathrm{~W}$ 八ロゲン電球を用いた開 11 径 $200 \mathrm{~mm}$ のスポットライトを上向き点灯し, その前面に 3 種 類のサンプルを設㯰して光照射による促進試験を行った。そし

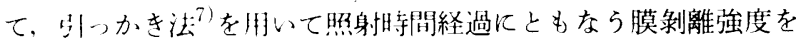

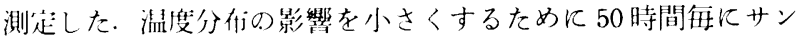

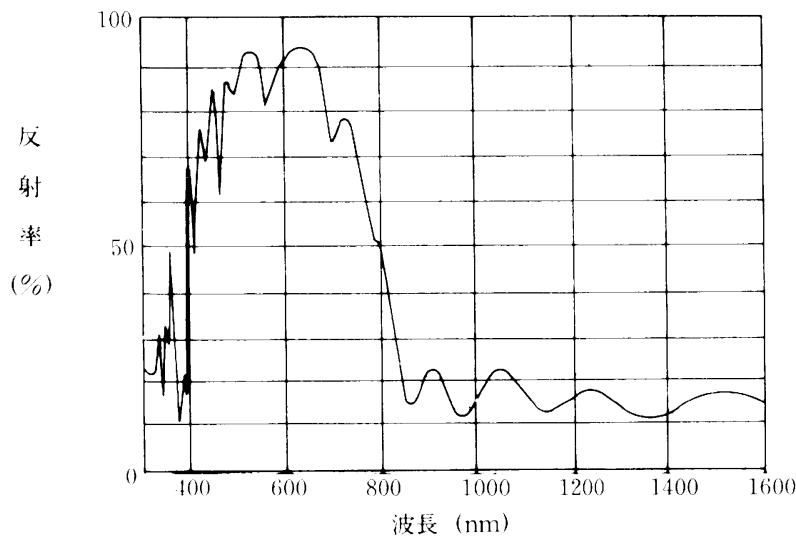

図4 PES 基板ダイクロイックミラーの分光反射率

プルを回転させた．尚，サンプルの置かれた 3 力所の表面温度は 180 190 ${ }^{\circ} \mathrm{C}$ であり, PES 基板に対しては, 形状を保持できる最 大の温度である。

図 5 Kは，剶離強度測定の一例を示す。横軸は引っかき時間を 示すが，時間に比例して引っかき針に力が加えられるため膜面に 与えられた荷重を意味することになる。縦軸は針の受けた電位信 号（任意値）を表示している．信号は針にかかる荷重の增加とと も几変化し，膜が剝離すると信号は大きく乱机，大きな出力が得 られるようになる。図中に示した写真の黒くなっている部分が膜 が剝離している所で，この部分で大きな信号の出力が得られた。 従って，破線間の荷重が膜を制離させるのに要したカであり，こ の力在槑離強度とした，測定に用いた条件は，針送りスピード $10 \mu \mathrm{m} / \mathrm{min}$, 荷重比 $31 \mathrm{mN} / \mathrm{min}$ である.

図6にPES 基板 DMKトップコートを施していないものと施 したものについて照射時間每の豩離強度の変動を示す. 測定はそ れぶれ3回行い, 罒中には平均值を示した。 また, トップコート の有無によって剩離強度が若干異なるため縦軸は相対值で示し 


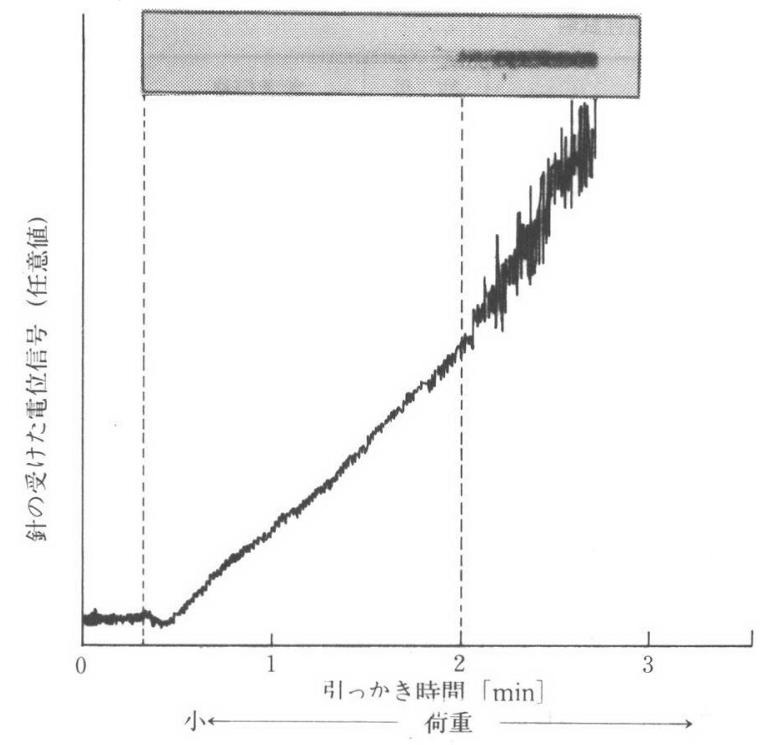

図 5 PES 基板上の光学薄膜の引っかき試験結果

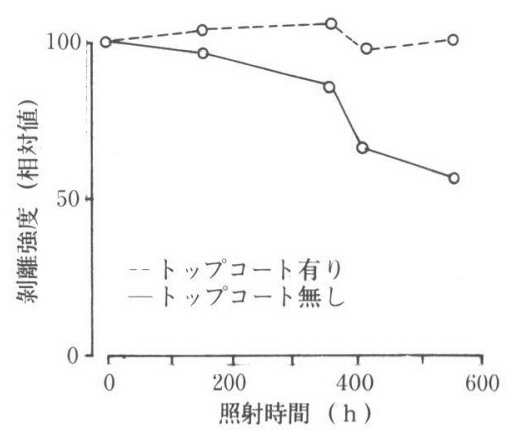

図 6 促進試験による多圈膜の剥離強度の変動 試験条件：試験光源 $500 \mathrm{~W}$ 八ロゲン電球 被照射面温度 $180 \sim 190^{\circ} \mathrm{C}$

た. トップコートを施さないPES 基板サンプルは，550 時間後 においても表 4 亿示した付着力試験や曲げ試験によるクラックや 剥離が生じることはないが，300時間を越えたあたりで剥離強度 の低下を示した．それに対し，トップコートを施したものは，乙 の試験時間内では初期状態を維持していることがわかる. 明らか にトップコートは効果を示し信頼性を向上させているものと思わ れる. 尚, こてでは示さなかったがPIフィルムの場合は, トッ プコートを施さなくてもこの試験に用いた温度下であれば PES フィルム基板 DM イトップコートを施したものと同様な試験結 果が得られている.

\subsection{3 光学的性能 (鏡面性)}

成形された反射鏡の光学特性を支配するものとして表面のらね り（歪み）上光沢度（鏡面性）があげられる. とれらは, 光の質 （ビームの鋭さ）や効率の低下となり現れる.

フィルム成形による反射鏡は, 肉厚が薄いために所々に表面に らねりを持ち, ビームのパターンに影響を与元る。しかし，一般 照明では組み合わせる光源が均一の発光体であることは少なく, ほとんどの反射鏡がその表面にファセットやディンプル ${ }^{8)}$ な゙のの 模様を施しビームパターンの均一化を図っている. 開発したフィ ルム成形品を用らた反射鏡においても表面に模様を形成するてと により, 成形時のらねりの影響を無視し均一なビームパターンを 得ることができる.

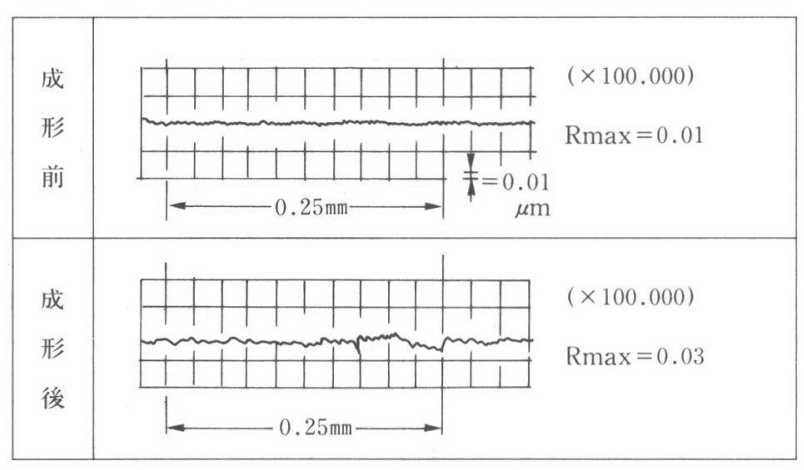

図 7 表面粗さ曲線

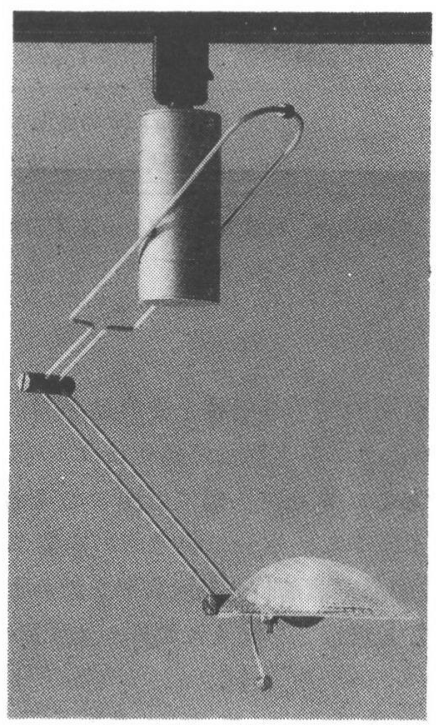

図 8 開発した照明器具の外観

$$
\begin{array}{ll}
\text { 使用光源 } & 12 \mathrm{~V} 50 \mathrm{~W} \text { ハロゲン電球 } \\
\text { 使用反射鏡 } & \mathrm{PES} \text { フィルム基板ダイクロイックミラー } \\
\text { 反射鏡寸法 } 135 \times 115 \times 40^{\mathrm{h}} \\
\text { 反射鏡表面ツチ目処理 }
\end{array}
$$

これに対し, 光沢度が小さいと光を散乱させ, 目標の方向へ光 を反射できなくると共に，照明率，ビーム効率の低下をもたら す. 図 7 に PES フィルムの成形前と成形後の表面粗さ ${ }^{9)}$ を示す. こてでは光沢度として表面粗さを代用した. 成形による表面粗さ の変化は非常に小さく, ガラスゃアルミ基板と同等以上の光沢度 を有している，てれまでの反射鏡と比へ，成形用の型表面の仕上 げ加工や成形品の表面を後工程で研磨などを必要とせず高い光沢 が得られるのもプラスチックフィルム反射鏡の特徵のひとつであ る.

\section{4. 照明器具への応用}

開発した反射鏡は厚さ 100〜300 $\mu \mathrm{m}$ と非常に薄いため, ほと んど重量感がなく, 外形や反射面の形状の自由度が高いものであ る. 基板材料としてPI フィルムを用いれば耐熱温度が高いため に今まで以上にプラスチックを基板とする反射鏡の小型化がで き, PES フィルムを用いればガラス基板と類似する光透過性を 利用した外観デザインを実現するととができる，とれらの特長を 生かし, “軽さ感”をコンセプトとして, 非常に軽量化された $\mathrm{PES}$ フィルム基板の DM と $12 \mathrm{~V} 50 \mathrm{~W}$ ハロゲン電球の組み合わ 


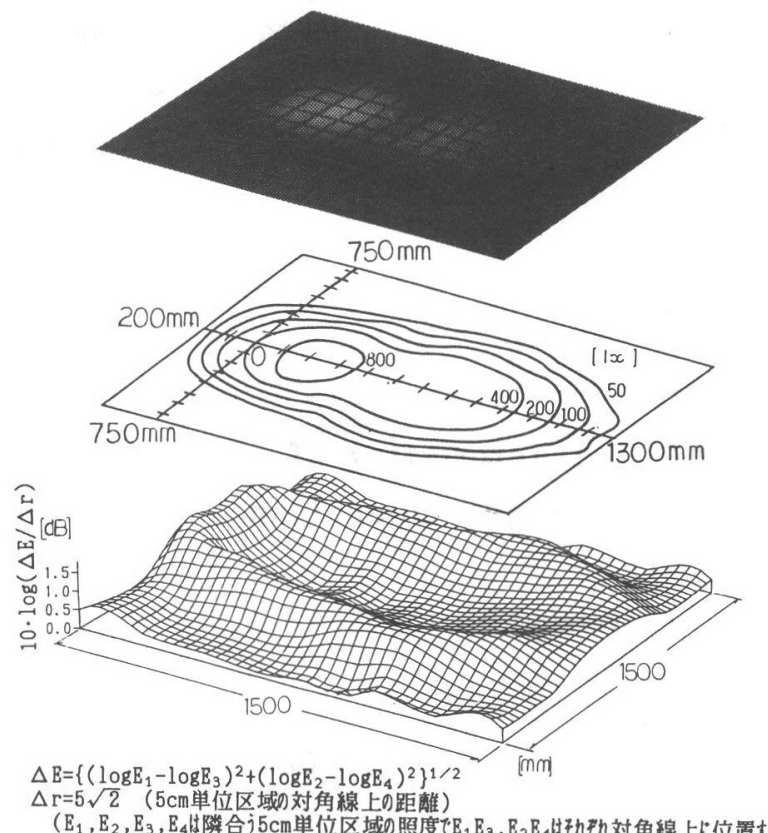

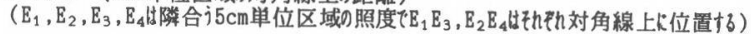

図 9 開発した器具の照度分布

（上から，照射面の写真，照度分布，照度変化率分布を示す）

せた器具を開発した.

図 8 亿今回開発した DM を用いた照明器具の一例を示す. 反 射鏡形状は，従来の回転放物面形状から棈円放物面を有する非対 称形状を実現し, 器具デザインに新規性をもをせ, さらに非対称 な配光を得るよらにした。

図 9 にこの照明器具 $1 \mathrm{~m}$ 下の反射鏡の開口面と水平な面の照 度分布を示す. 図は斜め方向から見たよらに変形させ，照射パタ ーンがどの様なビームの輪郭や鋭さをもっているか分かりやすく するため, 斜め方向からみた照射面の写真, 照度分布, 照度変化 率分布 ${ }^{10)}$ を立体的に表現したものである。照度測定は，A-A， B-B それぞれの方向に $5 \mathrm{~cm}$ 毎に行い，照度変化率分布は $5 \mathrm{~cm}$ 単位区域内の照度変化の勾配の対数值を補間してメッシュ表示を したものである．照度変化率分布の最も高い所がビームの輪郭を 表している.

開発した照明器具は, プラスチックフィルムを DMの基板に 応用するととにより，ガラスや金属の基板と同様な DM の機能 をもち, 光透過性と軽さを特長とした種々のデザインと非対称的 な配光を可能にした.

\section{5. まと め}

開発したプラスチックフィルムを用いた DM の仕様及び特長 を以下にをとめる。

- 仕様
1）基板材料 : PES 及び PI
2）上限使用温度 : $180^{\circ} \mathrm{C}$ (PES の場合), $240^{\circ} \mathrm{C}$ (PI の場合)
3) 許容最大寸法 : 開口径で $\phi 200 \mathrm{~mm}$ 程度

（現在までに確認された成形可能な寸法）
4）基板肉厚 : $0.1 \mathrm{~mm} \sim 0.3 \mathrm{~mm}$

(ただし，PI フィルムの場合は $0.125 \mathrm{~mm}$ 以下)

5) 重量 : 開口径 $\phi 150 \mathrm{~mm}$, 深さ $50 \mathrm{~mm}$ の場合, $4 \sim 9 \mathrm{~g}$

(ガラスに対し約 $1.4 \%$, アルミに対し約 $4 \%$ の重量 費)

- 特長

1）レろいろな形状の反射鏡が比較的簡単に作るととができ る.

2）超軽量な反射鏡を実現でき器具軽量化とともに斬新な照明 器具, 照明手法が期待できる.

\section{6. おわりに}

本稿では，プラスチックフィルム基板ダイクロイックミラーの 実用性を確認すると共に，とれを応用した器具の開発を行った。 てれにより, ダイクロイックミラーの基板としてガラス, 金属, 射出成形によるプラスチックに加えて, 新をにプラスチックフィ ルムがダイクロイックミラーの基板として使用できるようになっ た. これら基板材料の多様化は，例えば，ガラス基板はより小型 の DM として，大型なものに対応しやすい金属基板は出力の高 い投光器やスポットライト用の DM として, 形状に自由度があ り軽量なプラスチックフィルム基板は, デザイン性が強くカスタ ムメイドな器具や軽さを生かした可動型の器具の DM として, それぞれの特長を生かしながら，さらに様々な用途にダイクロイ ックミラーが使われるととを可能にすると考える.

参考文 献

(1) 大友, 井上：ネオジウムタイプハロゲンランプ, 照学全大 (昭 63)

(2) 白鳥, 福住 : ダイクロイックミラー<ネオジウム色〉ハロ ゲンランプの諸特性，照学全大（昭 63）

(3) 丸山，松下：ハロゲンランプ用高色温度変換反射鏡の開 発, 照学全大 (平01)

（4）梶山, 橋端，高橋 : 金属基委ダイクロイックミラーの薄膜 設計シミュレーションの開発とその応用, 照学誌 73-10 (平 01 )

(5) PROGRESS REPORT 1990, Light. Des. Appl. 20-11 (1990) p5

(6) Macleod, H. A. : THIN-FILM OPTICAL FILTERS, Adam Hiiger (1986)

(7) Baba, S., Kikuchi, A. and Kinbara, A. : J. Vac. Sci. Technol., A4 (1986) 3015 ; J. Vac. Sci. Technol., A5 (1987) 1860

(8) 山中, 真辺, 村上：ミニハロゲン電球用反射板設計につい $\tau$, 照学全大 (平01)

（9）松下，高橋，梶山，瀬名波：蒸着反射鏡を用んた高効率投 光器の開発, 照学誌 64-10 (昭 55)

(10) Kemenade, J. T. C. and Reker, J. : Beam Characteristics for Accent Lighting, Illum. Eng'ng. Soc. 17-2 (1988) $118-130$

(受付 1991 年 4 月 10 日) 